\title{
Edmodo E-Learning Analysis using End-User Computing Satisfaction Method \\ (Case Study: Senior High School 1 Sampang)
}

\author{
$1^{\text {st }}$ Khusnia Nur Rachmah \\ Information System \\ UPN “Veteran" Jawa Timur \\ Surabaya, Indonesia \\ 18082010008@student.upnjatim.ac.id
}

\author{
$2^{\text {nd }}$ Ahmad Nashirul Haq \\ Information System \\ UPN "Veteran" Jawa Timur \\ Surabaya, Indonesia \\ 18082010028@student.upnjatim.ac.id
}

\author{
$3^{\text {rd }}$ Nur Hasan Assobarry \\ Information System \\ UPN "Veteran" Jawa Timur \\ Surabaya, Indonesia \\ 18082010007@student.upnjatim.ac.id
}

\author{
$4^{\text {rd }}$ Fariza Nanda Sabila \\ Information System \\ UPN “Veteran” Jawa Timur \\ Surabaya, Indonesia \\ 18082010009@student.upnjatim.ac.id
}

\author{
$5^{\text {th }}$ Tri Lathif Mardi Suryanto, S.Kom, M.T. \\ Information System \\ UPN “Veteran” Jawa Timur \\ Surabaya, Indonesia \\ trilathif.si@upnjatim.ac.id
}

\begin{abstract}
The development of information technology that is growing in all aspects of life affects all human work to become more efficient and effective. The current COVID-19 pandemic is a condition where people's activities are hampered and limited in their daily activities. The application of Information Technology is a solution that can be applied to the continuity of community activities in the midst of this pandemic, one of which is the field of education. Edmodo's E-Learning system is one of the most widely used e-learning systems for learning activities. The application of e-learning certainly changes the way students learn from offline to online. EUCS (end-user computing satisfaction) is one of the evaluation metrics that focuses on end-user satisfaction with technological aspects which include: content, accuracy, format, ease of use, and timeliness. The case study of Senior High School 1 Sampang will be the object of this research, where the EUCS method is used to measure the satisfaction of end users of the Edmodo E-Learning system. Data was collected by distributing questionnaires to active students at Senior High School 1 Sampang by obtaining a sample of 80 respondents. From the results of the research conducted, it was found that the EUCS method could be applied to the Edmodo E-Learning system at Senior High School 1 Sampang because the data obtained from the respondents was declared valid and reliable. In measuring end-user satisfaction with the Edmodo E-learning system, the EUCS method factors that affect the end-user satisfaction of the Edmodo E-Learning system at Senior High School 1 Sampang are content and accuracy factors.
\end{abstract}

Keywords-edmodo; EUCS; e-learning; senior high school 1 sampang

\section{INTRODUCTION}

Information technology that is growing at this time makes a school easy to disseminate information. In line with this, a school is required to be able to optimize technology to support the teaching and learning process, arrange lesson schedules, collect assignments, collect student grade data, and attendance to facilitate the performance of students, teachers, and staff. One form of utilization of information technology for a school can be done through the application of academic information systems or e-learning, so that the demands of the needs in the teaching and learning process can be carried out flexibly [1], [2].

During the current COVID-19 pandemic, the conditions for community activities, of course, are hindered and restricted for students. As a letter released to enhance the Minister of Education and Culture's circular letter number 4 of 2020, Circular Letter Number 15 of 2020 was also issued, which contains the implementation of learning from home during the COVID-19 pandemic. The objectives of implementing Learning from Home (BDR) are stated in SE Number 15 of 2020, namely: (1) ensuring the fulfillment of students' rights to obtain educational services during the COVID-19 emergency; (2) protect education unit residents from the adverse effects of COVID-19; (3) prevent the spread and transmission of COVID-19 in education units; and (4) ensuring the fulfillment of psychological support for educators, students and parents/guardians [3]. Therefore, the ease and accuracy of information technology in a school is very necessary because the COVID-19 pandemic has changed the way students learn from offline to online.

Senior High School 1 Sampang is the oldest and most favorite high school in Sampang, Madura [4]. The Edmodo Elearning system, which has been established at Senior High School 1 Sampang, is a website-based e-learning service utilized by active students at Senior High School 1 Sampang. It 
may be used at any time and from any location as long as it is linked to the internet. Like many other web-based e-learning applications, there are options that Edmodo gives its users, including becoming a teacher, student, or being a parent of students. Edmodo has an account system using an email address or username that can be created using a Google, Microsoft, Apple, or G-Suite account obtained by active students from schools.

Quoting the article Sorongan (2019), The user satisfaction factor is one of the primary foundations for evaluating a system, and it is important to evaluate the quality of an information system [5]. End-user computing satisfaction (EUCS) approach is one of the most extensively used ways for determining the level of end-user happiness with an information system or website [6], [7].

The EUCS method based by Torkzadeh (1988) [8] contains five variables: content, accuracy, format, ease of use, and timeliness, and it is one of the methods used to measure user satisfaction of an information system. Content describes the accuracy, suitability of needs, and information contained in an information system. Accuracy has an understanding of errors that rarely occur and the accuracy when data is processed by a system in providing the needs and information needed. The format describes the size of the output (design) that is displayed how it looks comfortable and contains aesthetic elements in the system. Ease of use describes the extent to which a system can be run and does not confuse users when used. Timeliness describes how a system can provide information or data according to user needs (up to date) [6], [9].

The goal of this study, as stated above, is to employ the EUCS method to assess end-user satisfaction with the Edmodo E-Learning system by delivering questionnaires to active students at Senior High School 1 Sampang.

\section{THEORITICAL BACKROUND}

\section{A. Edmodo}

Edmodo is a system that is used for students or all available resources to achieve the goals to be achieved. The users in this system are teachers, students, and parents. Edmodo has an account system using an email address or username that can be created using a Google, Microsoft, Apple, or G-Suite account obtained by active students from schools.

\section{B. E-learning}

E-learning as a form of distance learning refers to the use of internet technology to provide various solutions for the advancement of skills and knowledge[10]. According to Dong (2001), e-learning is defined as asynchronous learning activities with computer electronics where learning materials are obtained as needed. This definition makes e-learning learning activities cannot be equated with learning activities in traditional classrooms, because asynchronous can be interpreted as physical separation that is not limited by time and place. Computer-based learning activities or distance learning (telecourses) that use a synchronous format cannot be classified as e-learning because both require the presence of learning participants at the same time or at a certain location [11].

\section{End-User Computing Satisfaction (EUCS)}

End-User Computing Satisfaction (EUCS) is a metric that may be used to assess how satisfied users are with a system. This measurement will compare the results of the experience in using the system with the expected results desired by the end user (user). EUCS is an evaluation metric based by William J. Doll and Gholamreza Torkzadeh which focuses more on enduser satisfaction with technological aspects which include: content, accuracy, format, ease of use, and timeliness [8].

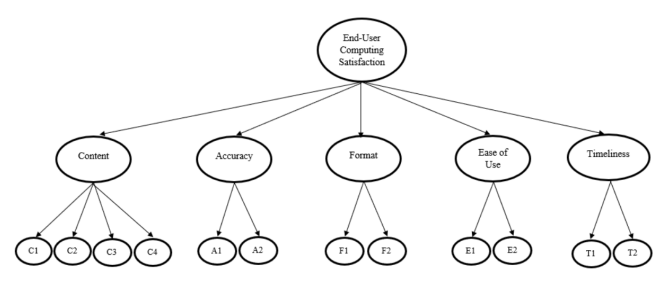

Fig. 1. EUCS Model

There are 5 variables measured by the End-User Computing Satisfaction method [8] [12].

\section{1) Content}

Content is one aspect that will be assessed in this EUCS method. Measurements will be made based on data, content, information, or posts in a system, in this case, a website. The content contained can also be seen to what extent it is useful for the end user (user).

\section{2) Accuracy}

Accuracy is one aspect that is assessed in this EUCS method. Measurements will be made on the accuracy of the content or information displayed on what is needed by the end user (user). This measurement focuses on data processing carried out by the system so that errors that occur are kept to a minimum.

\section{3) Format}

Format or layout is one aspect that is assessed in this EUCS method. Measurement is done by measuring how the level of satisfaction is based on the model format or layout of the display given by the system to the user.

\section{4) Ease of Use}

Ease of use is one of the aspects assessed in this EUCS method. Measurement is done by assessing whether users can use the existing flows and processes in the system.

\section{5) Timeliness}

The time period is one of the aspects assessed in this EUCS method. Measurement is done by assessing the extent to which the system responds to commands given by the user (realtime). The speed of the system in displaying, as well as providing input and output to the process that occurs is an aspect that needs to be assessed in improving system development. 


\section{RESEARCh MEthodology}

\section{A. Research Model}

In this work, we used Torkzadeh's (1988) EUCS model as a conceptual model to assess end-user satisfaction with Edmodo at Senior High School 1 Sampang (Fig. 2). We used the original version of EUCS instruments, which we customized to fit Edmodo's needs. We create a structured questionnaire for respondents to fill out.

The following hypotheses will be tested based on the research model:

H1. Content is a variable that will affect the end user's computing satisfaction

H2. Accuracy is a variable that will affect the end user's computing satisfaction

H3. Format is a variable that will affect the end user's computing satisfaction

H4. Ease of Use is a variable that will affect the end user's computing satisfaction

H5. Timeliness is a variable that will affect the end user's computing satisfaction

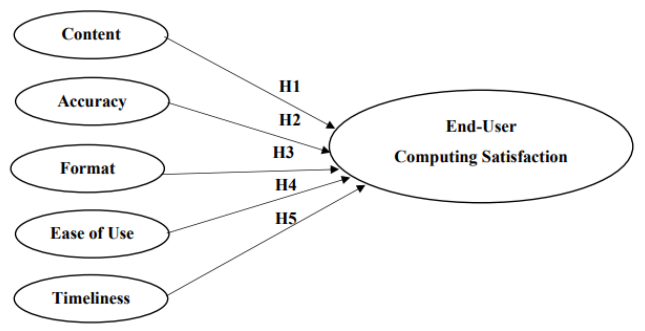

Fig. 2. Research Model

\section{B. Data Collection}

We deployment a questionnaire on the number of active students at Senior High School 1 Sampang using the Edmodo e-learning system, namely 96 students, which was obtained from an estimate of $10 \%$ of 32 students multiplied by the number of 30 classes. This number is the total population obtained from observations and interviews which state that the number of students who use the Edmodo e-learning system is in the range of $10 \%$. The sample used was obtained from the sampling technique, namely probability sampling, especially in the simple random sampling technique. In calculating the sample size, the Slovin technique is used with an accuracy rate of $95 \%$ and an error interval of $5 \%$. The questionnaire measured using a Likert scale consisting of: strongly disagree to strongly agree with an interval of score 1-5 [13]. Calculation of sample size with the Slovin technique can be shown in the following equation:
Where,

$\mathrm{n}$ : number of samples

$\mathrm{N}$ : total population

E : interval error 5\%(0.05)

So based on the equation above, the sample obtained is 77.42 which is rounded up to 80 respondents with the following calculation:

$$
\begin{aligned}
& n=\frac{96}{1+\left(96 \times 0.05^{2}\right)} \\
& n=\frac{96}{1.24} \\
& n=77.42 \rightarrow 80
\end{aligned}
$$

\section{Data Analysis Method}

After the data collection is complete, the data will be analyzed. We used SmartPLS software to check and validate the data obtained by using inferential analysis. The steps that can be taken can be seen in the following stages:

- Outer Model

Outer model analysis is used to determine the relationship between latent variables and their latent indicators. It can also be said that how are the goals and objectives of each variable and its indicators that influence each other [14]. Validity and reliability testing can be used to assess the outer model's analysis. Instrument validity and reliability testing is required to guarantee that the instrument in use is both valid and reliable. Validity testing on convergent validity requires a loading factor value of $>0.70$ and an Average Variance Extracted (AVE) value of $>0.50$. While reliability testing, the Cronbach's alpha value must be greater than $>0.60$ and the composite reliability value must be greater than $>0.70$.

\section{- Inner Model}

Inner model analysis, also known as inner relation, structural model, or substantive theory, is a method of describing the relationship between latent variables using substantive theory [15]. R-square for the dependent construct and Q-square for predictive relevance, as well as $\mathrm{t}$-test and the significance of the coefficients of the structural path parameters, can be used to evaluate the inner model's analysis.

\section{RESULT AND DISCUSSIONS}

The results and discussion in this study include a discussion of the demographic characteristics respondents, inferential analysis, and hypothesis testing which will be explained as follows.

$$
\alpha+\beta=\chi
$$




\section{A. Demographic Characteristic Respondents}

Respondents of this study were taken from the object of research, Senior High School 1 Sampang. The results of the analysis carried out, it was found that not all students at Senior High School 1 Sampang used Edmodo, so from the calculations carried out only students who used Edmodo filled out this questionnaire and found 80 the number of respondents exceeded the lower limit of the calculated target, namely 78 respondents.

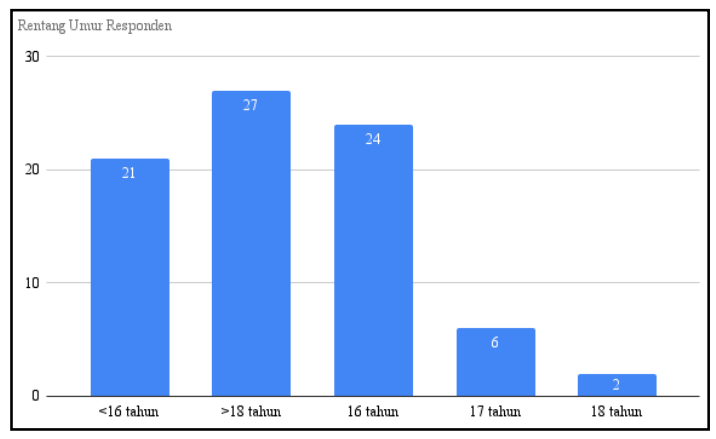

Fig. 3. Bar chart of the respondents's age

When presented in a pie chart it will be as follows:

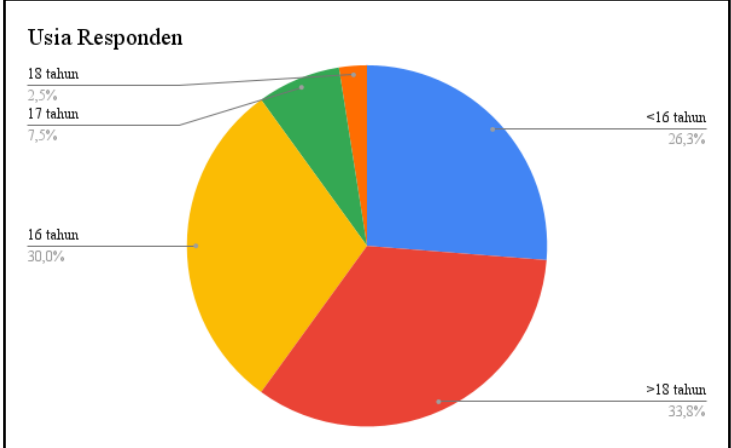

Fig. 4. Pie chart of the respondents's age

Respondents are also differentiated by gender as follows:

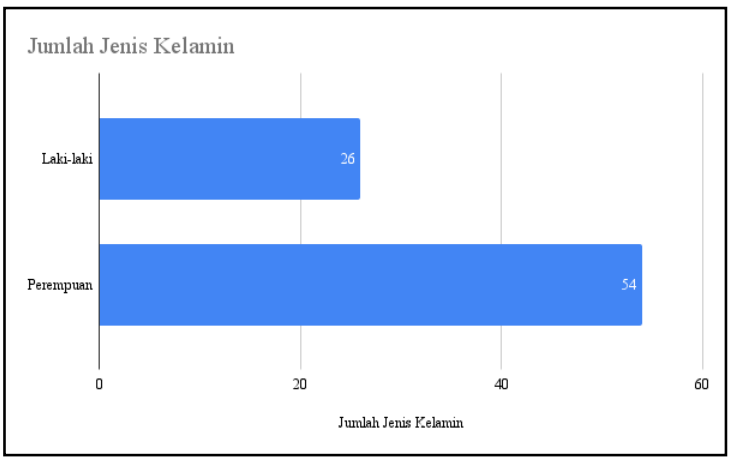

Fig. 5. Bar chart of the respondents's gender

Respondents are also differentiated by major as follows:

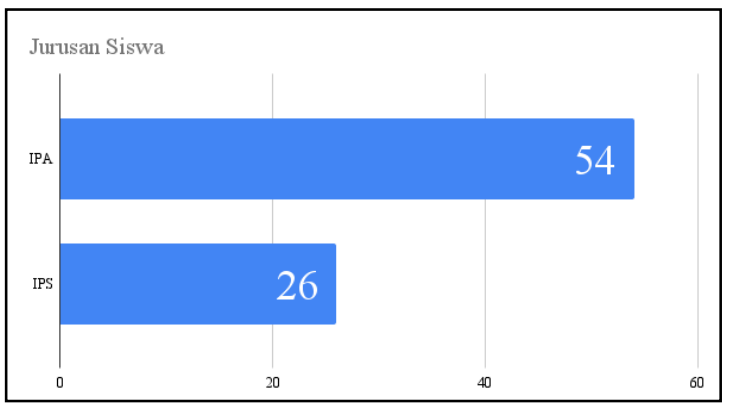

Fig. 6. Bar chart of the respondents's major

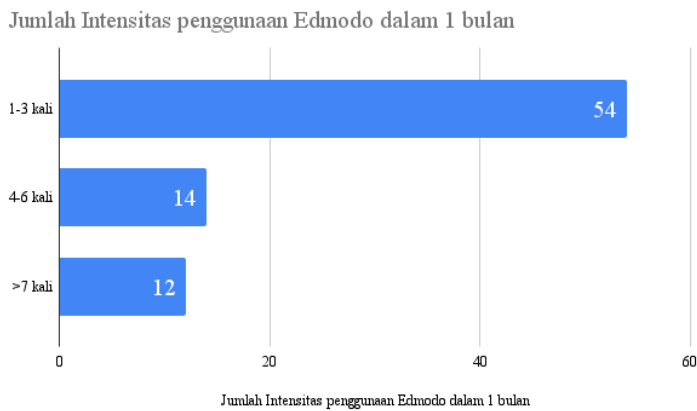

Fig. 7. Bar chart of the respondents's intension using Edmodo in 1 month

From the total number of respondents, it was found that the age of respondents who filled out this questionnaire was dominated by over 18 years with a total of 27 people, then 16 years old respondents totaling 24 people, less than 16 years old as many as 21 people, six respondents 17 years old, and two respondents 18 years. Respondents who filled out this questionnaire were also dominated by female gender and dominated by science majors.

\section{B. Inferential Analysis}

- Outer Model

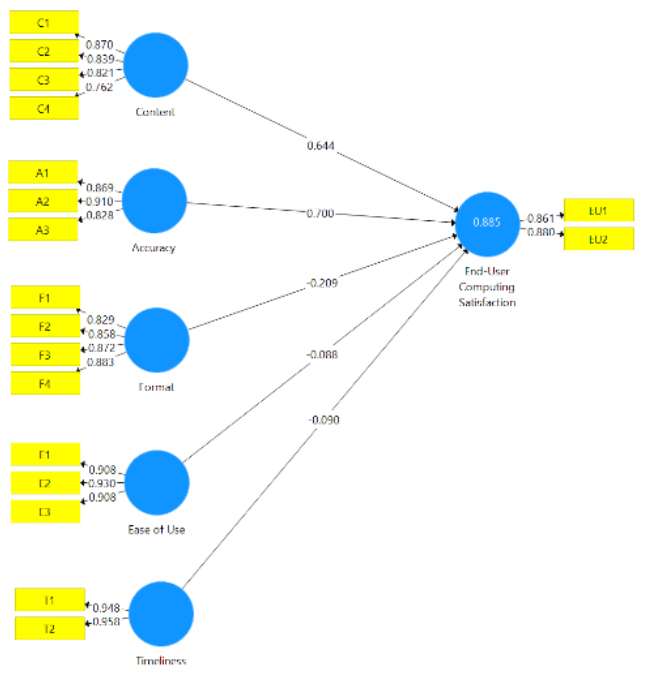

Fig. 8. Outer Model 
Fig. 8 is an image of the outer model, where for more details, you can see the image result of outer model.

\begin{tabular}{|c|c|c|c|c|c|c|}
\hline Variabel & Indikator & $\begin{array}{l}\text { Loading } \\
\text { Factor }\end{array}$ & AVE & $\begin{array}{l}\text { Discriminant } \\
\text { Validity }\end{array}$ & $\begin{array}{l}\text { Composite } \\
\text { Reliability }\end{array}$ & $\begin{array}{l}\text { Cronbach's } \\
\text { Alpha }\end{array}$ \\
\hline & $\mathrm{C} 1$ & 0.870 & & & & \\
\hline & C2 & 0.839 & & & & \\
\hline \multirow[t]{3}{*}{ Content } & C3 & 0.821 & 0.678 & 0.824 & 0.894 & 0.843 \\
\hline & C4 & 0.762 & & & & \\
\hline & A1 & 0.869 & & & & \\
\hline \multirow[t]{4}{*}{ Accuracy } & A2 & 0.910 & 0.756 & 0.870 & 0.903 & 0.839 \\
\hline & A3 & 0.828 & & & & \\
\hline & F1 & 0.829 & & & & \\
\hline & F2 & 0.858 & & & & \\
\hline \multirow[t]{3}{*}{ Format } & F3 & 0.872 & 0.741 & 0.861 & 0.920 & 0.883 \\
\hline & $\mathrm{F} 4$ & 0.883 & & & & \\
\hline & E1 & 0.908 & & & & \\
\hline \multirow[t]{3}{*}{ Ease of Use } & E2 & 0.930 & 0.838 & 0.916 & 0.940 & 0.903 \\
\hline & E3 & 0.908 & & & & \\
\hline & T1 & 0,948 & & & & \\
\hline Timeliness & T2 & 0.958 & 0.908 & 0.953 & 0.952 & 0.899 \\
\hline End-User & EU1 & 0.861 & & & & \\
\hline $\begin{array}{l}\text { Computing } \\
\text { Satisfaction }\end{array}$ & EU2 & 0.880 & 0.758 & 0.871 & 0.862 & 0.681 \\
\hline
\end{tabular}

Fig. 9. Result of Outer Model

Validity and reliability testing can be used to evaluate the analysis of the outer model based on the results of Fig. 8 and Fig. 9. In the validity testing, the loading factor value for convergent validity used as a validity requirement must be $>$ 0.70 and the Average Variance Extracted (AVE) value must be $>0.50$. Meanwhile, the square root of the AVE is the discriminant validity value, which is the value in the diagonal column that must be greater than the correlation between latent variables in the same column (above or below). In the reliability testing, the composite reliability value must be > 0.70 as a reliability requirement, while the Cronbach's alpha value must be $>0.60$ for the reliability requirement. As a result, the overall validity and reliability of this study have been met.

- Inner Model

TABLE I. INNER MODEL

\begin{tabular}{|c|c|c|}
\hline \multirow{2}{*}{ Variable } & \multicolumn{2}{|c|}{ Result } \\
\cline { 2 - 3 } & R-Square $^{\text {a }}$ & Q-Square $^{\text {a }}$ \\
\hline $\begin{array}{c}\text { End-User } \\
\text { Computing } \\
\text { Satisfaction }\end{array}$ & $0.885^{\text {a }}$ & $0.885^{\text {a }}$ \\
\hline
\end{tabular}

${ }^{\text {a. }}$ Result refers to SmartPLS 3.3.3 (2021) output.

The finding of the R-Square value is used to measure the level of variation of the change in the independent variable on the dependent variable, according to the results in Table I, which is $88.5 \%$ and it can also be interpreted that the Q-Square value must be greater than zero $(0)$, so this is shows that the value of Q-Square is $88.5 \%$. This shows that the level of diversity of the independent variable model in describing the dependent variable is $88.5 \%$ while the remaining $11.5 \%$ is influenced by other factors. From these findings, this research model can be classified as having Goodness of Fit.

\section{Hypothesis Testing}

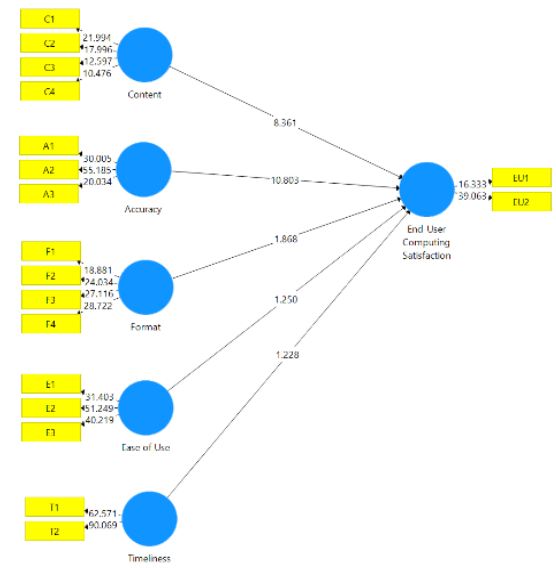

Fig. 10. Hypothesis Testing

Fig. 10 is an image of the hypothesis testing, where for more details, see the following table of hypothesis testing results.

TABLE II. HYHOTHESIS TESTING RESULT

\begin{tabular}{|c|c|c|c|c|}
\hline & \multicolumn{4}{|c|}{ Result } \\
\hline & $\begin{array}{c}\text { Original } \\
\text { Sample }^{\text {b }}\end{array}$ & T statistics ${ }^{b}$ & $\rho$ values ${ }^{b}$ & $\begin{array}{c}\text { Hypothesis } \\
\text { Result }^{\text {b }}\end{array}$ \\
\hline $\mathrm{A} \rightarrow \mathrm{EU}$ & 0.7000 & 10.803 & 0.000 & Accepted \\
\hline $\mathrm{C} \rightarrow \mathrm{EU}$ & 0.6440 & 8.361 & 0.000 & Accepted \\
\hline $\mathrm{E} \rightarrow \mathrm{EU}$ & -0.088 & 1.250 & 0.212 & Rejected \\
\hline $\mathrm{F} \rightarrow \mathrm{EU}$ & -0.209 & 1.868 & 0.602 & Rejected \\
\hline $\mathrm{T} \rightarrow \mathrm{EU}$ & -0.090 & 1.228 & 0.220 & Rejected \\
\hline
\end{tabular}

If seen in the results in Table II, where there are original sample values (regression coefficient), $\mathrm{T}$ Statistics, and $\rho$ values. $T$ Statistics value is greater than the $T$ table value with values $<0.05$ and a significance value $>1.96$, it can be said that there is a significant effect. As for the original sample value (regression coefficient) which has a negative sign, it can be called a negative effect.

According to the results of the analysis, receiving some of the key findings from the end-user satisfaction survey of the Edmodo E-learning system can be seen in Table III below:

TABLE III. KEY FINDINGS FROM THE HYHOTHESIS RESULT

\begin{tabular}{|c|c|c|}
\hline \multicolumn{3}{|c|}{ Hypothesis Result $^{\text {C }}$} \\
\hline H1 & $\begin{array}{c}\text { Content can be approved since has a } \\
\text { considerable positive effect on end-user } \\
\text { computing pleasure }\end{array}$ & Accepted \\
\hline H2 & $\begin{array}{c}\text { Accuracy can be approved since has a } \\
\text { considerable positive effect on end-user } \\
\text { computing pleasure }\end{array}$ & Accepted \\
\hline H3 & $\begin{array}{c}\text { Format was rejected because it did not } \\
\text { have a appreciable positive effect on the } \\
\text { end-user's computing pleasure. }\end{array}$ & Rejected \\
\hline
\end{tabular}




\begin{tabular}{|c|c|c|}
\hline H4 & $\begin{array}{c}\text { Ease of Use variable was rejected because } \\
\text { it did not have a appreciable positive effect } \\
\text { on the end-user's computing pleasure. }\end{array}$ & Rejected \\
\hline H5 & $\begin{array}{c}\text { Timeliness was rejected because it did not } \\
\text { have a appreciable positive effect on the } \\
\text { end-user's computing pleasure. }\end{array}$ & Rejected \\
\hline
\end{tabular}

c. Result refers to SmartPLS 3.3.3 (2021) output.

\section{CONCLUSIONS}

The results obtained from the results of data processing carried out with 80 respondents are: the end-user computing satisfaction method can be applied to the Edmodo E-Learning system at Senior High School 1 Sampang because the data obtained from all respondents is declared valid and reliable, so it can be relied upon in measuring satisfaction. end users of the Edmodo e-learning system. Overall, content and accuracy factors played a key role in increasing end-user satisfaction (all respondents), whereas format, ease of use, and timeliness factors did not play an important role in increasing end-user satisfaction (all respondents). Suggestions from this research that can be given are:

- The accuracy factor can be the most influential factor to improve the quality of the Edmodo e-learning system, so it can be focused first on that section so that user satisfaction is maintained, then it can be continued with improving the factors: content (especially on the $\mathrm{C} 4$ indicator), ease of use (especially on the E1 indicator), format (especially on the $\mathrm{C} 4$ indicator). indicator $\mathrm{F} 1$ ), and timeliness (especially on indicator F1), because these indicators have the smallest value in the Fig. 10 hypothesis testing.

- Future research is expected to use evaluation of enduser satisfaction with other methods, such as TAM, Delone and McLean, etc.

\section{REFERENCES}

[1] W. Wardiana, "Perkembangan Teknologi Informasi di Indonesia," Semin. dan Pameran Teknol. Informasi, Fak. Tek. Univ. Komput. Indones., 2002, doi: 10.1007/BF02191578.

[2] A. Saputra and D. Kurniadi, "Analisis Kepuasan Pengguna Sistem Informasi E-Campus di IAIN Bukittinggi Menggunakan Metode EUCS," Voteteknika, 2019, doi: 10.24036/voteteknika.v7i3.105157.

[3] Kemendikbud, "Pedoman Penyelenggaraan Belajar Dari Rumah Dalam Masa Darurat Penyebaran Corona Virus Disease (Covid-19)," Surat Edaran Nomor 15 Tahun 2020, no. 021, pp. 1-20, 2020.
[4] "SMAN 1 SAMPANG." https://smansampang1.sch.id/ (accessed Dec. 16, 2021).

[5] E. Sorongan, H. Hilmansyah, and H. Hadiyanto, "Pengaruh Variabel Kualitas Sistem Informasi Terhadap Kepuasan Pengguna Sistem Informasi Model EUCS," J. RESTI, 2019, doi: 10.29207/resti.v3i1.777.

[6] B. Prasetyo, R. W. E. Yulia, and Felisia, "Measuring End-User satisfaction of Online Marketplace using End-User Computing Satisfaction Model (EUCS Model) (Case Study: Tokopedia.com)," Proc. 2017 4th Int. Conf. Comput. Appl. Inf. Process. Technol. CAIPT 2017, 2018, doi: 10.1109/CAIPT.2017.8320710.

[7] A. Subiyakto, R. Rosalina, M. C. Utami, N. Kumaladewi, and S. J. Putra, "The Psychometric and Interpretative Analyses for Assessing The End-User Computing Satisfaction Questionnaire," 5th Int. Conf. Cyber IT Serv. Manag., 2017, doi: 10.1109/CITSM.2017.8089282.

[8] W. Doll and G. Torkzadeh, "The Measurement of End-User Computing Satisfaction," Source MIS Q., 1988.

[9] D. Rachmawati, Nur Krisbiantoro, "Evaluasi Kepuasan Pengguna Sistem E-Learning Menggunakan Metode End User Computing Satisfaction (Studi Kasus : Universitas Amikom Purwokerto)," J. JOISM, 2021.

[10] A. H. Elyas, "Penggunaan Model Pembelajaran Elearning Dalam Meningkatkan Kualitas Pembelajaran," J. War., 2018.

[11] H. Kamarga, "E-LEARNING,” pp. 1-14, 1996.

[12] C. I. Nurmaini Dalimunthe, “Analisi Tingkat Kepuasan Pengguna Online Public Access Catalog (OPAC) Dengan Metode EUCS," J. Rekayasa dan Manaj. Sist. Inf., 2016.

[13] Sugiyono, Metode Penelitian Pendekatan Kuantitatif, Kualitatif dan $R \&$ D. 2015.

[14] I. Ghozali and H. Latan, Partial Least Squares Konsep, Teknik dan Aplikasi Menggunakan Program SmartPLS 3.0 untuk Penelitian Empiris. Semarang: Universitas Diponegoro, 2015.

[15] N. Aini, D. Ridwandono, and M. Safitri, "Analisis Kepuasan Pengguna Sistem Informasi Akademik di Univerisitas Bhayangkara Surabaya," J. JIFOSI, 2021. 